\title{
The effect of timing of oral meloxicam administration on physiological responses in calves after cautery dehorning with local anesthesia
}

\author{
K. A. Allen, ${ }^{*}$ J. F. Coetzee, ${ }^{* 1,2}$ L. N. Edwards-Callaway, $\dagger^{3}$ H. Glynn, $\dagger$ J. Dockweiler, ${ }^{*}$ B. KuKanich, $\ddagger$ H. Lin, $\S$ \\ C. Wang,§ E. Fraccaro,\# M. Jones, ${ }^{* 4}$ and L. Bergamasco*5 \\ *Department of Clinical Sciences, College of Veterinary Medicine, \\ †Department of Animal Science, College of Agriculture, and \\ †Department of Anatomy and Physiology, College of Veterinary Medicine, Kansas State University, Manhattan 66506 \\ §Department of Statistics, lowa State University, Ames 50011 \\ \#Department of Animal Pathology, Division of Pharmacology and Toxicology, University of Turin, 10124 Turin, Italy
}

\begin{abstract}
Dehorning is a painful husbandry procedure that is commonly performed in dairy calves. Parenteral meloxicam combined with local anesthesia mitigates the physiological and behavioral effects of dehorning in calves. The purpose of this study was to determine the influence of timing of oral meloxicam administration on physiological responses in calves after dehorning. Thirty Holstein bull calves, 8 to 10 wk of age $(28-70 \mathrm{~kg})$, were randomly assigned to 1 of 3 treatment groups: placebo-treated control group $(\mathrm{n}=10)$, calves receiving meloxicam administered orally $(1 \mathrm{mg} / \mathrm{kg})$ in powdered milk replacer $12 \mathrm{~h}$ before cautery dehorning (MEL-PRE; $\mathrm{n}=10$ ), and calves receiving meloxicam administered as an oral bolus $(1 \mathrm{mg} / \mathrm{kg})$ at the time of dehorning (MEL-POST; $\mathrm{n}=10$ ). Following cautery dehorning, blood samples were collected to measure cortisol, substance P (SP), haptoglobin, ex vivo prostaglandin $\mathrm{E}_{2}\left(\mathrm{PgE}_{2}\right)$ production after lipopolysaccharide stimulation and meloxicam concentrations. Maximum ocular temperature and mechanical nociceptive threshold (MNT) were also assessed. Data were analyzed using noncompartmental pharmacokinetic analysis and repeated measures ANOVA models. Mean peak meloxicam concentrations were $3.61 \pm 00.21$ and 3.27 $\pm 0.14 \mu \mathrm{g} / \mathrm{mL}$ with average elimination half-lives of $38.62 \pm 5.87$ and $35.81 \pm 6.26 \mathrm{~h}$ for MEL-PRE and MEL-POST, respectively. Serum cortisol concentra-
\end{abstract}

\footnotetext{
Received October 10, 2012.

Accepted April 17, 2013.

${ }^{1}$ Corresponding author: hans@coetzee.org

${ }^{2}$ Present address: Veterinary Diagnostic and Production Animal Medicine, College of Veterinary Medicine, Iowa State University, Ames 50011-1250.

${ }^{3}$ Present address: 1770 Promontory Circle, Greeley, CO 80634.

${ }^{4}$ Present address: College of Veterinary Medicine, Texas A\&M University, 4475 TAMU, College Station 77843.

${ }^{5}$ Present address: College of Agriculture and Life Sciences, Animal and Poultry Sciences Department, Litton Reaves Hall, Virginia Polytechnic Institute and State University, Blacksburg 24061.
}

tions were lower in meloxicam-treated calves compared with control calves at $4 \mathrm{~h}$ postdehorning. Substance $\mathrm{P}$ concentrations were significantly higher in control calves compared with meloxicam-treated calves at 120 $\mathrm{h}$ after dehorning. Prostaglandin $\mathrm{E}_{2}$ concentrations were lower in meloxicam-treated calves compared with control calves. Mechanical nociceptive threshold was higher in control calves at $1 \mathrm{~h}$ after dehorning, but meloxicam-treated calves tended to have a higher MNT at $6 \mathrm{~h}$ after dehorning. No effect of timing of meloxicam administration on serum cortisol concentrations, SP concentrations, haptoglobin concentrations, maximum ocular temperature, or MNT was observed. However, $\mathrm{PgE}_{2}$ concentrations in MEL-PRE calves were similar to control calves after $12 \mathrm{~h}$ postdehorning, whereas MEL-POST calves had lower $\mathrm{PgE}_{2}$ concentrations for $3 \mathrm{~d}$ postdehorning. These findings support that meloxicam reduced cortisol, $\mathrm{SP}$, and $\mathrm{PgE}_{2}$ after dehorning, but only $\mathrm{PgE}_{2}$ production was significantly affected by the timing of meloxicam administration.

Key words: welfare, dehorning, pain, meloxicam

\section{INTRODUCTION}

Consumer interest in animal welfare, especially pain associated with routine livestock management procedures such as castration and dehorning, is increasing (Rollin, 2004). The purpose of dehorning is to minimize the risk of injuries to caretakers and other animals and to decrease the incidence of carcass downgrading due to bruising and hide damage (Stewart et al., 2009). Although many benefits to dehorning exist, the procedure is considered painful in calves (AVMA, 2012).

In a survey of dairies in the north-central and northeastern United States, hot irons were identified as the most common dehorning method used. However, local anesthesia was only provided by $12.4 \%$ of dairy owners and systemic analgesics are used by only $1.8 \%$ of dairy owners (Fulwider et al, 2008). The American Veterinary Medical Association (AVMA, 2012) has stated the 
importance of minimizing pain associated with dehorning to reduce distress and changes in behavioral and physiological states. Though it has been reported that the combination of a local anesthetic and a nonsteroidal anti-inflammatory drug (NSAID) can mitigate the onset of pain associated with dehorning (Heinrich et al., 2009; Stewart et al., 2009; Coetzee, 2011), currently no FDA-approved NSAID labeled for pain management in food animals in the United States exists (Coetzee, 2013). Flunixin meglumine is the only NSAID approved for use in beef and dairy cattle, but it is only labeled for i.v. administration for the control of pyrexia associated with bovine respiratory disease and mastitis and for the control of inflammation associated with endotoxemia (FDA, 2006; Smith et al., 2008).

Several methods have been used to quantify the pain associated with dehorning (Stock et al., 2013). Although many pain-induced responses have been recognized, none of these are currently validated for scoring pain in cattle (Muir and Woolfe, 2001; Smith and Modric, 2013). Indicators of physiological change that can be measured in the blood include serum cortisol concentration (Heinrich et al., 2009), haptoglobin concentration (Earley and Crowe, 2002), and plasma substance P (SP) concentration (Coetzee et al., 2008, 2012). Other measures of pain include assessment of mechanical nociceptive threshold (MNT) using pressure algometry (Heinrich et al., 2010), ocular temperature (Stewart et al., 2008), behavioral measures (including ear flicks and head rubs; Faulkner and Weary, 2000; Heinrich et al., 2010), and heart and respiratory rates (Stewart et al., 2008, Heinrich et al., 2009; Coetzee et al., 2012).

Studies have indicated that an NSAID, such as ketoprofen and sodium salicylate, can mitigate responses to pain associated with hot iron dehorning in young dairy calves (Faulkner and Weary, 2000; Baldridge et al., 2011). Other studies found that meloxicam administration ameliorates the physiological stress response to dehorning following intramuscular or intravenous injection (Heinrich et al., 2009; Coetzee et al. 2012). Meloxicam is an NSAID in the oxicam class considered to bind preferentially to cyclo-oxygenase- 2 enzymes in cattle. Meloxicam has been approved for use in bovine in European countries as well as Canada as a single i.v. or s.c. dose of $0.5 \mathrm{mg} / \mathrm{kg}$, but is currently not approved for use in cattle in the United States (EMEA, 1999; Health Canada, 2011). Oral meloxicam tablets can be legally used to alleviate pain in cattle in the United States if used in accordance with the Animal Medicinal Drug Use Clarification Act of 1994 (AMDUCA). The specific conditions of AMDUCA include (1) extra-label drug use (ELDU) only by or under the supervision of a veterinarian; (2) ELDU only for FDA-approved animal and human drugs; (3) ELDU only when the health of the animal is threatened and not for production purposes; (4) no ELDU in feed; and (5) no ELDU if it results in a violative food residue (US FDA, 1994). A recent study determined that oral administration of meloxicam provides similar plasma drug concentrations to those achieved following parenteral administration (Coetzee et al., 2009). The study also concluded the plasma $\mathrm{T}$ half of oral meloxicam lasts approximately $28 \mathrm{~h}$ and therefore, meloxicam should provide effective analgesia for several days after oral administration (Coetzee et al., 2009). However, studies investigating the effect of oral meloxicam in calves experiencing dehorning with local anesthesia are currently deficient in the published literature.

Pre-emptive analgesia involves the administration of an analgesic compound before the onset of the noxious event, thus limiting the pain-stress-distress cascade that results when pain is induced (Anderson and Muir, 2005). When considering pre-emptive analgesia, it is hypothesized that meloxicam should be administered at least $12 \mathrm{~h}$ before dehorning so that the onset of the painful stimulus corresponds with peak plasma drug concentrations (Coetzee et al., 2009). Meloxicam may be conveniently administered in milk replacer $12 \mathrm{~h}$ before dehorning to provide pre-emptive analgesia as shown in Mosher et al. (2012). This study reported a similar plasma meloxicam concentration profile following coadministration of meloxicam tablets with powdered milk replacer, as was observed following administration of an oral bolus of meloxicam (Mosher et al., 2012). The purpose of the present study was to determine the overall effect of timing of oral meloxicam administration on physiological responses in calves after dehorning. This study had 2 primary objectives, namely (1) to assess the effect of oral meloxicam on pain response after dehorning with local anesthesia and (2) to determine if oral meloxicam is clinically more effective when given $12 \mathrm{~h}$ before a surgical procedure than when given at the time of the procedure.

\section{MATERIALS AND METHODS}

All experimental procedures in this study were approved by the Kansas State University Institutional Animal Care and Use Committee under the supervision of the university veterinarian (Protocol \# 2898).

\section{Animal Husbandry and Housing}

Thirty Holstein bull calves were obtained from a dairy in Boulder, Colorado, in May 2011. On arrival, calves were processed with a single s.c. dose of oxytetracycline $300 \mathrm{mg} / \mathrm{mL}$ (NoromycinTM 300 LA, Norbrook Inc., Lenexa, KS), a single s.c. dose of an 8-way clos- 
tridial vaccine (Covexin 8, Intervet/Schering-Plough Animal Health, Summit, NJ), and a single s.c. dose of a 4-way bovine respiratory disease vaccine (BoviShield GOLD 5, Pfizer Animal Health, New York, NY). A topical pour-on comprising $5 \%$ permethrin and $5 \%$ piperonyl butoxide (Ultra Boss Pour-On Insecticide, Intervet/Schering-Plough Animal Health) was applied to all calves and repeated as needed for fly control. Calves were castrated approximately 2 wk after arrival and given a further 2-wk acclimation period before study commencement. Calves were approximately 8- to 10 -wk-old at the time of dehorning. Housing consisted of 2 identical barns composed of twenty $9.29-\mathrm{m}^{2}$ individual stalls with concrete floors, per industry standard. One-half of each stall was shaded by a tin roof. Stalls were randomly assigned to calves upon arrival. Calves were fed a bottle consisting of $350 \mathrm{~g}$ of powdered milk replacer (Land O'Lakes Instant Amplifier Max, Land O'Lakes Inc., Shoreview, MN) with 2.18 $\mathrm{L}$ of water every $12 \mathrm{~h}$. Calves were also fed $0.68 \mathrm{~kg}$ of calf starter diet (KSU feedmill, Manhattan, KS) per day. The diet consisted of rolled corn, soybean hulls, dehydrated distillers grains, soybean mill, corn steep liquor, and a vitamin and mineral supplement. The diet was $87 \%$ DM with $16 \% \mathrm{CP}, 3.4 \%$ crude fat, and $10.4 \%$ crude fiber. Water was offered in buckets ad libitum.

\section{Study Procedure}

The study design was a randomized complete block design with 2 periods $24 \mathrm{~h}$ apart. Calves were ranked by ascending weight and assigned a random number using Microsoft Excel 2010 (Microsoft Corporation, Redmond, WA). Calves were approximately 8 to $10 \mathrm{wk}$ of age at the time of this study commencement and were blocked by weight that was obtained at castration 4 wk earlier. Each period consisted of 15 calves that were assigned, using random numbers, to 1 of 3 treatments ( $\mathrm{n}=5$ calves/treatment per period).

Jugular Catheterization. Approximately $12 \mathrm{~h}$ before dehorning for each period, calves were restrained in pens with a halter for catheter placement. The area of the left jugular vein was clipped and disinfected using povidone iodine and $70 \%$ isopropyl alcohol swabs. Prior to catheter placement, $0.5 \mathrm{~mL}$ of $2 \%$ lidocaine hydrochloride [Lidocaine $\mathrm{HCl} 2 \%$ (20 mg/mL), Hospira Inc., Lake Forest, IL] was injected subcutaneously over the jugular vein to provide analgesia before a 1-cm incision with a \#22 scalpel blade was made only through the skin. Next, a 14 gauge $\times 140-\mathrm{mm}$ jugular catheter [Abbocath-T (305 mL/min), Abbott Ireland, Sligo, Republic of Ireland] was inserted. Catheters were sutured in place and patency was maintained with $5 \mathrm{~mL}$ of heparin saline flush $(4 \mathrm{U} / \mathrm{mL})$. Catheters remained patent a total of $36 \mathrm{~h}$ and were removed after the $24-\mathrm{h}$ blood sample was collected.

Drug Administration. After randomization, meloxicam was administered to calves $12 \mathrm{~h}$ before dehorning (MEL-PRE), immediately after dehorning (MEL-POST), or a placebo control was administered (CONT). All calves were fed an individually prepared bottle approximately $12 \mathrm{~h}$ before dehorning. Calves assigned to the MEL-PRE treatment group received meloxicam [Meloxicam Tablets USP $15 \mathrm{mg}$ (NDC 98300-125-01), Unichem Pharmaceuticals USA Inc., Rochelle Park, NJ; Lot GMMH10108] at a dose of 1 $\mathrm{mg} / \mathrm{kg}$ and $25 \mathrm{~g}$ of whey powder (Spray Dried Pasteurized Whey, Kraft, Harford, CA) suspended in the bottle immediately before feeding. All other calves received only $25 \mathrm{~g}$ of whey powder as a placebo suspended in the bottle immediately before feeding. Calves assigned to the MEL-POST treatment were given gelatin capsules containing 15-mg meloxicam tablets administered at a dose of $1 \mathrm{mg}$ of meloxicam $/ \mathrm{kg}$ of BW and $12 \mathrm{~g}$ of whey powder at the time of dehorning. All other calves were given a bolus consisting of only $12 \mathrm{~g}$ of whey powder as a placebo at the time of dehorning.

Dehorning. Approximately 15 min before dehorning, calves were restrained in an individual stall with a rope halter. A cornual nerve block was performed with $5 \mathrm{~mL}$ of $2 \%$ lidocaine hydrochloride [Lidocaine $\mathrm{HCl} 2 \%$ (20 mg/mL), Hospira Inc.] on both sides as previously described (Stock et al., 2013). Ten minutes after the application of local anesthetic, horn bud sensitivity was tested with a needle prick using an 18 gauge needle around the horn bud. Both horn buds were then removed via a hot iron dehorning as previously described (Heinrich et al. 2010). To maintain consistency, all nerve blocks were performed by the same veterinarian (author J.F.C.) and all dehorning was performed by the same technician who was masked to treatment group.

\section{Data Collection}

Blood Sampling. Blood samples were collected using the aforementioned catheters at baseline (approximately $2 \mathrm{~h}$ before dehorning), immediately before dehorning $(-1 \mathrm{~min})$, and at 5, 30,60,120, 240,360, 480, and 720 min after dehorning. A blood sample drawn from the jugular vein using an 18 gauge needle was collected every $24 \mathrm{~h}$ thereafter for $7 \mathrm{~d}$. Additionally, a blood sample was taken at time of catheterization and before treatment administration to obtain a - 12-h drug concentration sample. Catheter patency was maintained using 5 $\mathrm{mL}$ of heparin saline flush both before and after blood was drawn and $3 \mathrm{~mL}$ of blood was discarded before the sample was taken. The samples were collected while the animals were haltered and tied in individual shaded 
stalls with access to water. Cortisol, SP, and drug concentrations were measured at every time point, whereas haptoglobin and $\mathrm{PgE}_{2}$ concentrations were analyzed at baseline (approximately $2 \mathrm{~h}$ before dehorning), 5 , 360, $720 \mathrm{~min}$, and every $24 \mathrm{~h}$ for $3 \mathrm{~d}$. Cortisol and haptoglobin analysis required $6 \mathrm{~mL}$ of blood collected into 2 separate serum clot activator tubes, blood for SP analysis was collected into 1 EDTA K3 tube, and drug concentration and $\mathrm{PgE}_{2}$ blood samples were collected into 2 separate lithium heparin tubes (Vacuette $6 \mathrm{~mL}$ lithium heparin, Greiner Bio-One, Kremsmunster, Austria). The EDTA K3 tubes and lithium heparin tubes were stored on ice and the serum clot activator tubes were stored at room temperature before centrifugation.

Algometer Measurements. Mechanical nociceptive threshold was measured by an algometer (Wagner Force One FDIX, Wagner Instruments, Greenwich, $\mathrm{CT}$ ) at baseline (approximately $2 \mathrm{~h}$ before dehorning), $-1,60,120,240,360,480,720 \mathrm{~min}$, as well as at the 24-h blood sample for $7 \mathrm{~d}$ after dehorning as previously described (Heinrich et al., 2010). Each calf was restrained with a halter and a hand was placed lightly on the poll until the calf habituated to being touched and stood in a relaxed posture. The hand was then slowly removed and replaced with the algometer rubber tip placed directly beside the horn wound, such that the rubber tip covered the cautery wound and the edge of normal tissue. Pressure was applied perpendicular to the poll at a rate of approximately $1 \mathrm{kgf} / \mathrm{s}$ until the calf withdrew its head. The right horn was measured first and the 3 sites around each horn bud were measured in the same order for each horn. The technician was masked to the algometer reading until after the calf withdrew its head and, to maintain consistency, the same technician took every algometer reading.

Thermography Imaging. Changes in maximum ocular temperature (MOT) were measured using a commercially available infrared inspection system (ThermaCAM P65HS, FLIR Systems, Wilsonville, OR) as previously described. All images were taken on the left side, at a 90 degree angle, and approximately $0.5 \mathrm{~m}$ away from the subject (Stewart et al., 2009). Maximum temperatures within the lacrimal caruncle were recorded. Images were obtained at baseline (approximately $2 \mathrm{~h}$ before dehorning), $-1,1$, and $720 \mathrm{~min}$ after dehorning. Images were analyzed for changes in maximum ocular temperature using research grade software (Thermacam Researcher Pro 2.8 SR-1, FLIR Systems).

Weight Measurements. Weights were obtained at time of catheterization and at time of the 7 -d blood draw postdehorning. Calves were weighed in a hydraulic squeeze chute (Daniels Manufacturing Co., Ainsworth, $\mathrm{NE})$.

\section{Sample Analysis}

All sample analysis was conducted by technicians that were masked to treatment group allocation.

Cortisol Analysis. For every time point, $6 \mathrm{~mL}$ of blood was collected into serum clot activator tubes and centrifuged at $1,500 \times g$ for $10 \mathrm{~min}$ at $4^{\circ} \mathrm{C}$ within 30 min of collection. The serum was collected with transfer pipettes and stored in 2-mL cryogenic vials and frozen at $-80^{\circ} \mathrm{C}$ before cortisol analysis. Serum cortisol concentrations were determined using solid-phase competitive chemiluminescent enzyme immunoassay and an automated analyzer system (Immulite 1000 Cortisol, Siemens Medical Solutions, Los Angeles, CA). This method has been validated in the Kansas State Veterinary Diagnostic Laboratory (Coetzee et al., 2007).

Haptoglobin Analysis. For selected time points, $6 \mathrm{~mL}$ of blood was collected into serum clot activator tubes and centrifuged at $1,500 \times g$ for $10 \mathrm{~min}$ at $4^{\circ} \mathrm{C}$ within $30 \mathrm{~min}$ of collection. The serum was then pipetted off using $3-\mathrm{mL}$ transfer pipettes into $2-\mathrm{mL}$ cryogenic vials and stored at $-80^{\circ} \mathrm{C}$ before haptoglobin analysis. The method of analysis depends on the peroxidatic activity of hemoglobin. Hemoglobin added in excess to serum samples binds to haptoglobin and becomes resistant to acid inactivation. In contrast, the peroxidatic activity of free hemoglobin is lost. The serum haptoglobin concentration is calculated using a standard curve prepared by incubating known amounts of hemoglobin with a serum sample containing a concentration of haptoglobin greater than $150 \mathrm{mg} / \mathrm{dL}$.

$\boldsymbol{P g E}_{2}$ Analysis. Blood samples were collected into lithium heparin tubes and stored on ice for no longer than $30 \mathrm{~min}$ before incubation and analysis for plasma $\mathrm{PgE}_{2}$ concentrations. For each time point, $3 \mathrm{~mL}$ of whole blood was incubated in glass tubes for $24 \mathrm{~h}$ at $37^{\circ} \mathrm{C}$, with the exception of baseline sample. The baseline sample was divided into 2 different aliquots: 3 $\mathrm{mL}$ incubated with LPS $(\mathrm{K}+)$ and another $3 \mathrm{~mL}$ incubated without LPS $(\mathrm{K}-$ ) used as positive and negative control of basal levels of $\mathrm{PgE}_{2}$. The LPS (diluted in PBS and used at $10 \mu \mathrm{g} / \mathrm{mL}$ ) was added to the samples to stimulate ex vivo $\mathrm{PgE}_{2}$ production by monocytes. At the end of incubation, all samples were centrifuged at $400 \times g$ for $10 \mathrm{~min}$ at $4^{\circ} \mathrm{C}$ to obtain plasma. The resulting supernatant was taken and stored at $-80^{\circ} \mathrm{C}$ until the determination of plasma $\mathrm{PgE}_{2}$ levels using an ELISA kit (Prostaglandin $\mathrm{E}_{2}$ Kit, Cayman Chemical Company, Ann Arbor, MI) previously validated in our laboratory (Fraccaro et al., 2013).

SP Analysis. Blood samples were collected into EDTA K3 tubes containing the protease inhibitor, benzamidine hydrochloride (Benzamidine Hydrochloride, Santa Cruz Biotechnology Inc., Santa Cruz, CA). A 20 
$\mathrm{m} M$ solution of benzamidine was prepared in water and $300 \mu \mathrm{L}$ was added to each tube for a final concentration of $1 \mathrm{~m} M$ benzamidine in whole blood to serve as a protease inhibitor. These tubes were stored on ice for no more than 30 min before being centrifuged at 1,500 $\times$ $g$ for $10 \mathrm{~min}$ at $4^{\circ} \mathrm{C}$. The plasma was pipetted off with 3 -mL transfer pipettes and stored in 2-mL cryogenic vials and stored at $-80^{\circ} \mathrm{C}$ until analysis. Analysis of SP was performed as previously described (Coetzee et al., 2008).

Plasma Drug Analysis. Plasma concentrations of meloxicam $(\mathrm{m} / \mathrm{z} \quad 352.09 \rightarrow 114.90)$ were determined with HPLC (Shimadzu Prominence, Shimadzu Scientific Instruments, Columbia, MD) and MS (API 2000, Applied Biosystems, Foster City, CA). Plasma samples or standards $(50 \mu \mathrm{L})$ were added to $200 \mu \mathrm{L}$ of internal standard (piroxicam $0.5 \mu \mathrm{g} / \mathrm{mL}$ in methanol, $\mathrm{m} / \mathrm{z} 332.12 \rightarrow 95.10$, and pregabalin $5 \mu \mathrm{g} / \mathrm{mL}, \mathrm{m} / \mathrm{z}$ $160.00 \rightarrow 142.00)$ in methanol with $0.1 \%$ formic acid to precipitate the proteins. The samples were vortexed for $5 \mathrm{~s}$ and centrifuged at $10,000 \times g$ for $10 \mathrm{~min}$ at $4^{\circ} \mathrm{C}$. The supernatant, $200 \mu \mathrm{L}$, was transferred to an injection vial with the injection volume set to $10 \mu \mathrm{L}$. The mobile phase consisted of acetonitrile and $0.1 \%$ formic acid at a flow rate of $0.4 \mathrm{~mL} / \mathrm{min}$. The mobile phase consisted of $100 \%$ formic acid from 0 to $30 \mathrm{sec}$ with a linear gradient to $50 \%$ formic acid at $2.5 \mathrm{~min}$, which was maintained until $5 \mathrm{~min}$, followed by a linear gradient to $100 \%$ formic acid at $5.5 \mathrm{~min}$ with a total run time of $8 \mathrm{~min}$. Separation was achieved with a C18 column (Supelco Discovery, $50 \times 2.1 \times 5 \mu \mathrm{m}$, Sigma, St. Louis, MO) and maintained at $40 \mathrm{C}$. The standard curve was linear from 0.025 to $5 \mu \mathrm{g} / \mathrm{mL}$ for meloxicam and the standard curves were accepted if the correlation coefficient exceeded 0.99 and predicted values were within $15 \%$ of the actual values. The accuracy of the assay was 102,99 , and $100 \%$ of the actual value at $0.025,0.5$, and $5 \mu \mathrm{g} / \mathrm{mL}$, respectively, on replicates of 5 for each concentration. The coefficient of variation was 6,3 , and $3 \%$ at $0.025,0.5$, and $5 \mu \mathrm{g} / \mathrm{mL}$, respectively, on replicates of 5 for each concentration.

\section{Data Analysis}

Pharmacokinetic Analysis. Noncompartmental pharmacokinetic analyses were performed with computer software (WinNonlin 5.2, Pharsight Corporation, Mountain View, CA). The variables calculated included the area under the curve (AUC) from time 0 to infinity using the linear trapezoidal rule, area under the first moment curve from time 0 to infinity, plasma clearance per fraction of the dose absorbed, apparent volume of distribution (area method) per fraction of the dose absorbed, first-order rate constant, terminal half-life, and mean residence time extrapolated to infinity. The percent of the AUC extrapolated to infinity (AUC extrapolated) was determined. The maximum serum concentration $\left(\mathbf{C}_{\max }\right)$ and time to maximum plasma concentration were determined directly from the data.

Statistical Analysis. Models were fit using the GLIMMIX procedure of SAS (Version 9.2, SAS Institute, Cary, NC). Model assumptions were considered to be appropriately met using externally studentized residuals. Differences in means of the response variables between analgesia (the combination of MEL-PRE and MEL-POST) versus no analgesia (CONT) and the mean difference interactions with time were assessed using F-tests in the repeated measures ANOVA models. Effects of timing of treatment administration and time on response variables were similarly analyzed using repeated measures ANOVA models. Treatment, time, and their interaction were used as fixed effects, whereas calf was the subject of the repeated measures. Serum cortisol concentration, serum haptoglobin concentration, and algometer measurements were log-transformed before analyses to stabilize the distribution variances. Relevant pairwise comparisons were conducted using Tukey-Kramer adjustments to avoid inflation of Type I error rate due to multiple comparisons. A significance level of $\alpha=0.05$ was used to determine statistical differences, as well as $\alpha \leq 0.10$ for assessing effects with marginally significant differences, especially with respect to time by treatment interactions.

\section{RESULTS}

No calves were removed from this study.

\section{Cortisol Concentration}

Overall, evidence of an effect of time on mean cortisol concentrations across treatment groups $(P<0.0001)$ and a time by analgesia treatment interaction $(P=$ 0.047 ) was observed. To clarify the time by treatment interaction, the mean cortisol concentration was graphed versus time (Figure 1). Calves that received meloxicam had significantly lower serum cortisol concentrations compared with placebo-treated controls at $4 \mathrm{~h}$ after dehorning $(P=0.0004)$. Comparison between individual treatment groups revealed that mean cortisol concentration was significantly lower in both the MEL-PRE $(P=0.015)$ and MEL-POST $(P=0.002)$ compared with the CONT calves at this time point.

\section{SP Concentration}

Evidence of a time by treatment interaction on SP concentrations after dehorning was observed. This 

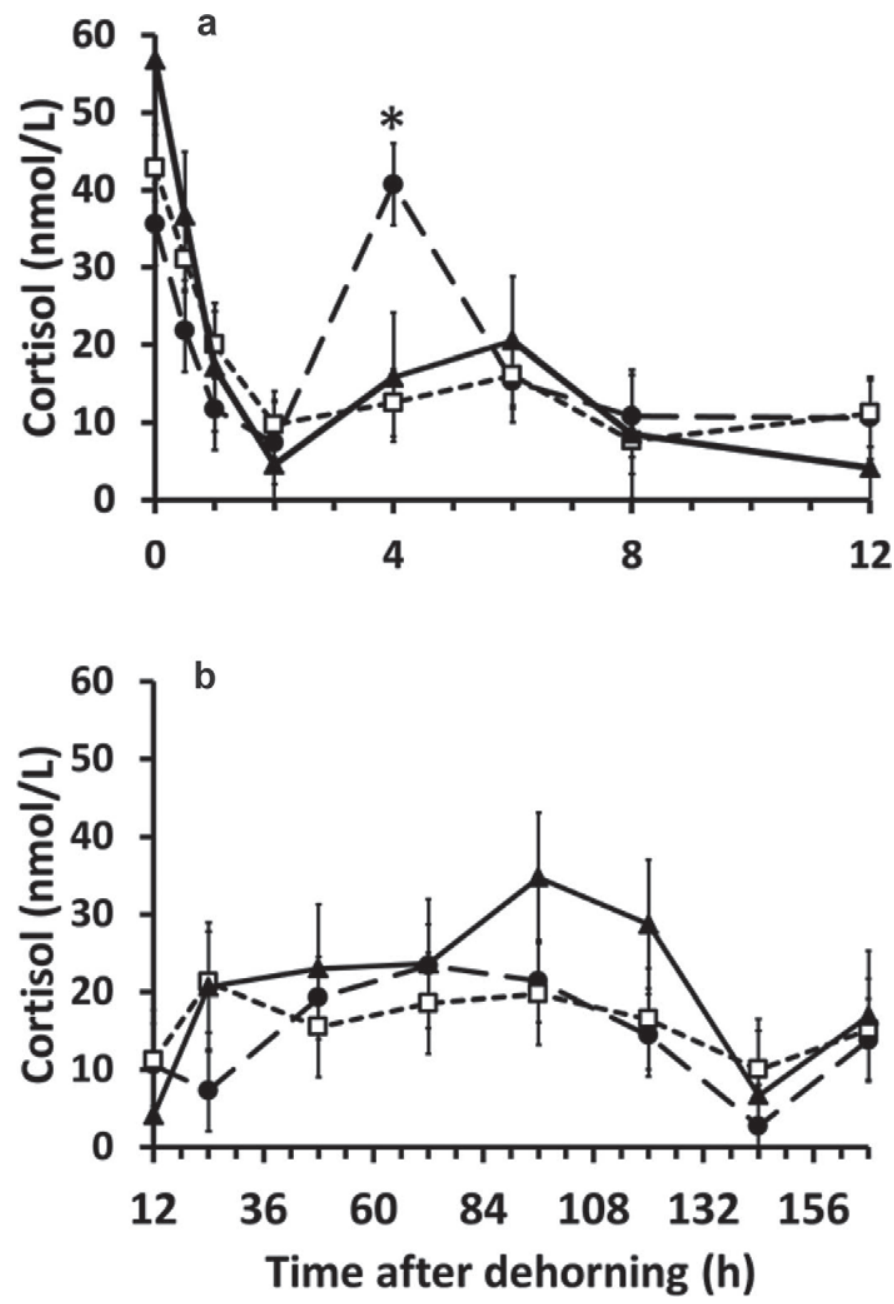

Figure 1. Mean \pm SEM serum cortisol concentrations in dairy calves dehorned ( $\mathrm{n}=10$ calves/group) with meloxicam administration $12 \mathrm{~h}$ before dehorning $(\boldsymbol{\Lambda})$, meloxicam administered at the time of dehorning $(\square)$, and the control group with no meloxicam administered (๑). Time of dehorning was designated as time 0. Serum cortisol concentrations were lower in meloxicam-treated calves compared with control calves at $4 \mathrm{~h}$ postdehorning $\left({ }^{*} P=0.0004\right)$.

interaction is illustrated in Figure 2, which compares mean plasma SP concentration against time for the analgesia group and placebo-treated control group. At $120 \mathrm{~h}$ postdehorning, calves given analgesia had a significantly lower SP concentration then those not given analgesia $(P=0.039)$.

\section{Haptoglobin Concentration}

Mean serum haptoglobin concentration increased significantly over time across all treatment groups $(P$ $=0.0046)$. The comparison of mean haptoglobin concentrations postdehorning and time are summarized in Figure 3 for all 3 treatment groups. It is noteworthy that a significant increase in haptoglobin concentra- tions was observed between 12 and $72 \mathrm{~h}$ postdehorning as well as between 24 and $72 \mathrm{~h}$ postdehorning $(P=$ 0.0077 and 0.0297 , respectively) across all treatment groups but no treatment effect was observed.

MOT

Evidence of an effect of time on MOT across all 3 treatment groups $(P<0.0001)$ was observed. The mean MOT at baseline, 1 min predehorning, 1 min, and $12 \mathrm{~h}$ postdehorning for all 3 treatment groups is summarized in Figure 4. The graph demonstrates that, compared with baseline (-120 min) values, MOT was significantly decreased at $1 \mathrm{~min}$ predehorning and 1
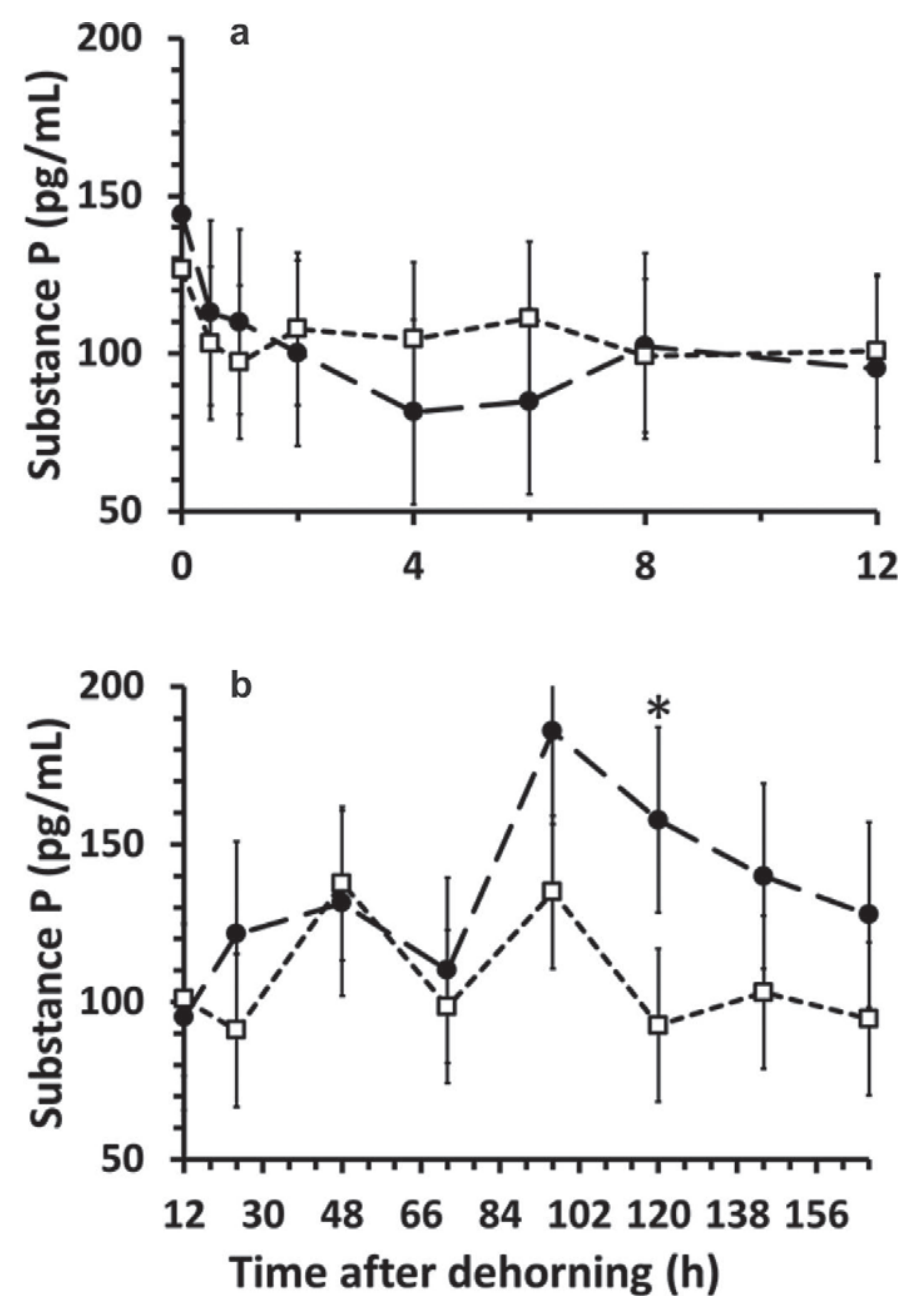

Figure 2. Mean \pm SEM plasma substance $\mathrm{P}$ concentration in dairy calves dehorned ( $\mathrm{n}=10$ calves/group) with meloxicam administration either $12 \mathrm{~h}$ before dehorning or at the time of dehorning $(\square)$ and control group with no meloxicam administered $(\bullet)$. Time of dehorning was designated as time 0 . Substance $\mathrm{P}$ concentrations were significantly higher in placebo-treated control calves compared with meloxicamtreated calves at $120 \mathrm{~h}$ after dehorning $\left({ }^{*} P=0.038\right)$. 


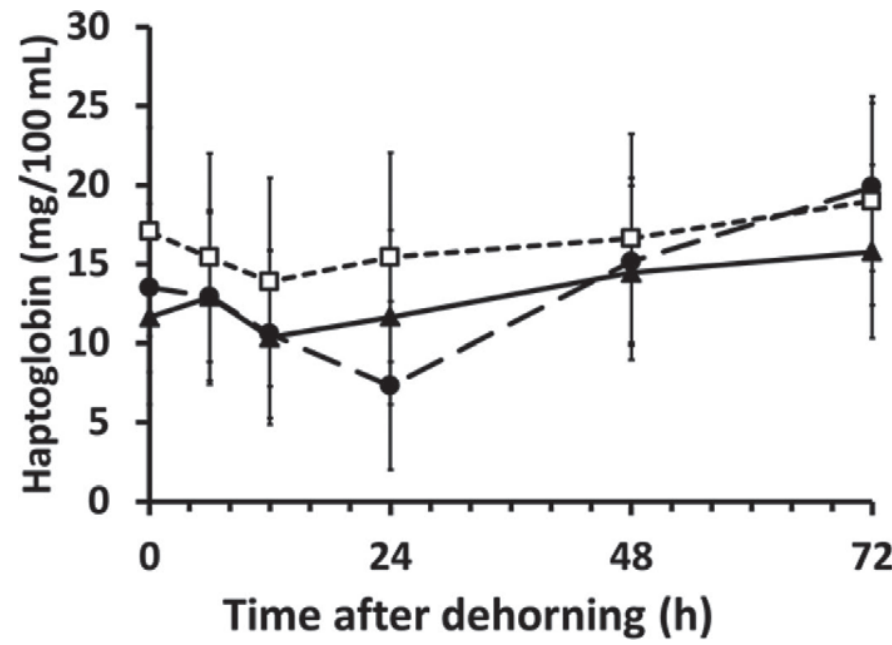

Figure 3. Mean \pm SEM haptoglobin concentration in dairy calves dehorned ( $\mathrm{n}=10$ calves/group) with meloxicam administration $12 \mathrm{~h}$ before dehorning $(\mathbf{\Lambda})$, meloxicam administered at the time of dehorning $(\square)$, and control group with no meloxicam administered $(\bullet)$. Time of dehorning was designated as time 0 . Concentrations did not differ significantly $(P=0.8573)$ between groups.

min postdehorning $(P<0.0001$ for both) across all treatment groups.

\section{$\mathrm{PgE}_{2}$ Concentration}

The administration of meloxicam had a significant effect on plasma $\mathrm{PgE}_{2}$ concentrations when compared with the placebo-treated control group. Specifically, the

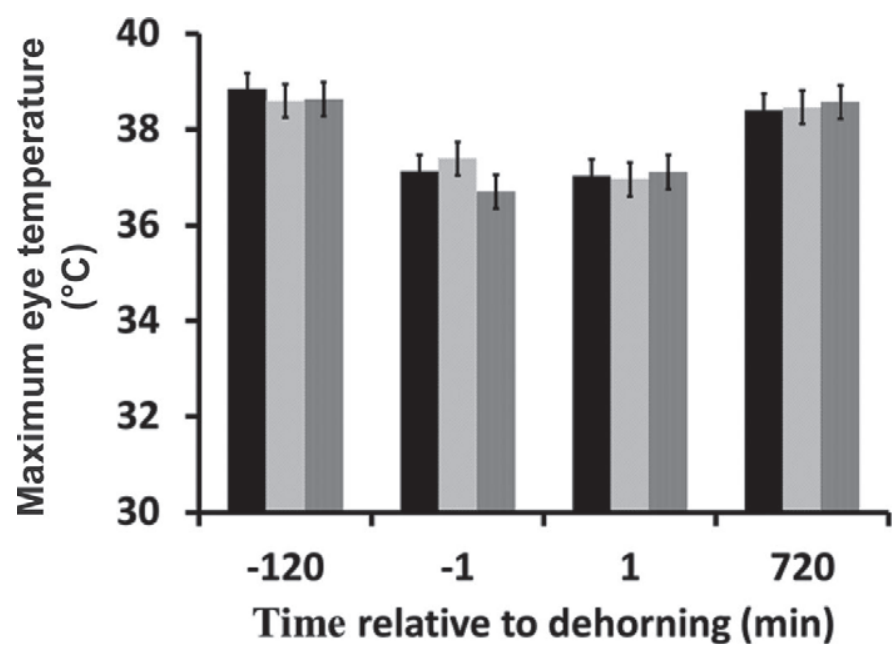

Figure 4. Mean \pm SEM maximum ocular temperature in dairy calves dehorned ( $\mathrm{n}=10$ calves/group) with meloxicam administration $12 \mathrm{~h}$ before dehorning (dark gray bar), meloxicam administered at the time of dehorning (light gray bar), and control group with no meloxicam administered (solid black bar). Time of dehorning was designated as time 0 . Concentrations did not differ significantly $(P=0.9016)$ between groups. data revealed that the $\mathrm{PgE}_{2}$ concentration in calves that received meloxicam were an average of $309.68 \pm 84.4$ $\mathrm{pg} / \mathrm{mL}$ lower than calves that did not receive meloxicam $(P=0.0011)$. Additionally, a significant interaction between time and meloxicam administration was evident $(P=0.0489)$. These differences are further illustrated in Figure 5, which shows $\mathrm{PgE}_{2}$ concentrations against time for all 3 treatment groups. Specifically, at $6 \mathrm{~h}$ postdehorning, both MEL-POST and MEL-PRE had a significantly reduced $\mathrm{PgE}_{2}$ concentrations when compared with CONT calves $(P=0.0036$ and 0.0053 , respectively). Similarly, at $12 \mathrm{~h}$ postdehorning, the $\mathrm{PgE}_{2}$ concentrations of both MEL-POST and MELPRE treatment groups were significantly lower than the concentrations of the CONT calves $(P=0.0024$ and 0.0240 , respectively). However, at $24 \mathrm{~h}$ postdehorning, the $\mathrm{PgE}_{2}$ concentrations of the MEL-PRE calves $(P=0.0160)$ and the CONT calves $(P=0.0147)$ were significantly higher than the MEL-POST calves.

\section{MNT}

An effect of time on MNT $(P<0.0001)$ was observed. In particular, MNT was significantly elevated above baseline values for $2 \mathrm{~h}$ postdehorning $(P=0.0004)$. In contrast, at $4 \mathrm{~h}$ postdehorning, MNT was significantly less than baseline measurements $(P<0.0001)$. Evidence of a significant interaction of time and meloxi-

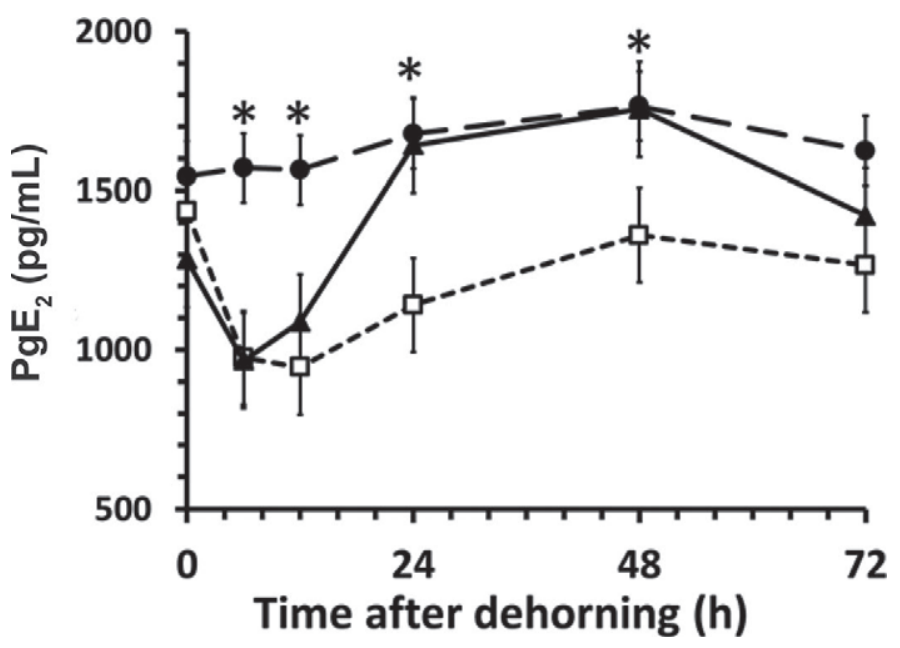

Figure 5. Mean \pm SEM plasma prostaglandin $\mathrm{E}_{2}\left(\mathrm{PgE}_{2}\right)$ concentration in dairy calves dehorned $(\mathrm{n}=10$ calves/group) with meloxicam administration $12 \mathrm{~h}$ before dehorning $(\boldsymbol{\Lambda})$, meloxicam administered at the time of dehorning $(\square)$, and control group with no meloxicam administered $(\bullet)$. Time of dehorning was designated as time 0 . Concentrations were significantly different $(P=0.0023)$ between groups. Further, $\mathrm{PgE} \mathrm{E}_{2}$ concentrations in calves receiving meloxicam administration $12 \mathrm{~h}$ before dehorning were similar to control calves after $12 \mathrm{~h}$ postdehorning, whereas calves administered meloxicam at the time of dehorning had lower $\mathrm{PgE}_{2}$ concentrations (designated with an asterisk) for $3 \mathrm{~d}$ postdehorning. 
cam administration $(P=0.0143)$ was also observed on amount of force tolerated by calves postdehorning. This difference is further illustrated in Figure 6, which displays MNT versus time for all 3 treatment groups. Specifically, at $1 \mathrm{~h}$ postdehorning the MNT was 0.2160 $\pm 0.09 \mathrm{kgf}$ higher in the placebo-treated control group than the group that received meloxicam analgesia $(P$ $=0.0168)$. Specifically, the MNT of the CONT calves tended to be higher when compared with the MELPRE calves $(P=0.0588)$ as opposed to MEL-POST calves $(P=0.1484)$. In contrast, calves that received analgesia had an MNT that was $0.1619 \mathrm{kgf}$ higher than those calves that did not receive meloxicam analgesia at $6 \mathrm{~h}$ postdehorning $(P=0.0728)$.

\section{ADG}

The average weight of the calves at baseline was 65.3 $\mathrm{kg}$, whereas the average weight of calves at $\mathrm{d} 7$ was $67.6 \mathrm{~kg}$. No evidence of an effect of the use of analgesia on ADG $(P=0.8689)$ was observed. Additionally, the timing of meloxicam administration was also not found to cause a significant difference on ADG $(P=0.9542)$.

\section{Meloxicam Pharmacokinetic Parameter Estimates}

Pharmacokinetic parameter estimates are summarized in Table 1 and include mean \pm SEM. The plasma drug concentration time curve is also characterized in Figures 7 and 8. The terminal half-life of MEL-POST and MEL-PRE was determined to be $35.81 \pm 6.26$ and $38.62 \pm 5.87 \mathrm{~h}$, respectively. The volume of distribution was very similar between the 2 treatments; MEL-POST and MEL-PRE were $0.28 \pm 0.04$ and $0.27 \pm 0.02 \mathrm{~L} / \mathrm{kg}$, respectively. The AUC was also very similar between the groups, as MEL-POST was $217.12 \pm 38.20(\mathrm{~h} \cdot \mu \mathrm{g} /$ $\mathrm{mL})$ and $216.12 \pm 40.05(\mathrm{~h} \cdot \mu \mathrm{g} / \mathrm{mL})$ for the MEL-PRE group. Although not statistically significant $(P=$ 0.1775 ), the $\mathrm{C}_{\max }$ of the MEL-PRE group was numerically higher at $3.61 \pm 0.21 \mu \mathrm{g} / \mathrm{mL}$ than the MEL-POST group $(3.27 \pm 0.14 \mu \mathrm{g} / \mathrm{mL})$.

\section{DISCUSSION}

The purpose of this study was 2-fold: (1) to assess the effect of oral meloxicam on the pain response and (2) to determine if oral meloxicam is clinically more effective when given $12 \mathrm{~h}$ before a surgical procedure than when given at the time of the procedure. The present study supports the hypothesis that oral meloxicam administration ameliorates the physiological response to dehorning similar to what has recently been reported following intramuscular or intravenous injection (Heinrich et al., 2009; Coetzee et al., 2012). Furthermore,
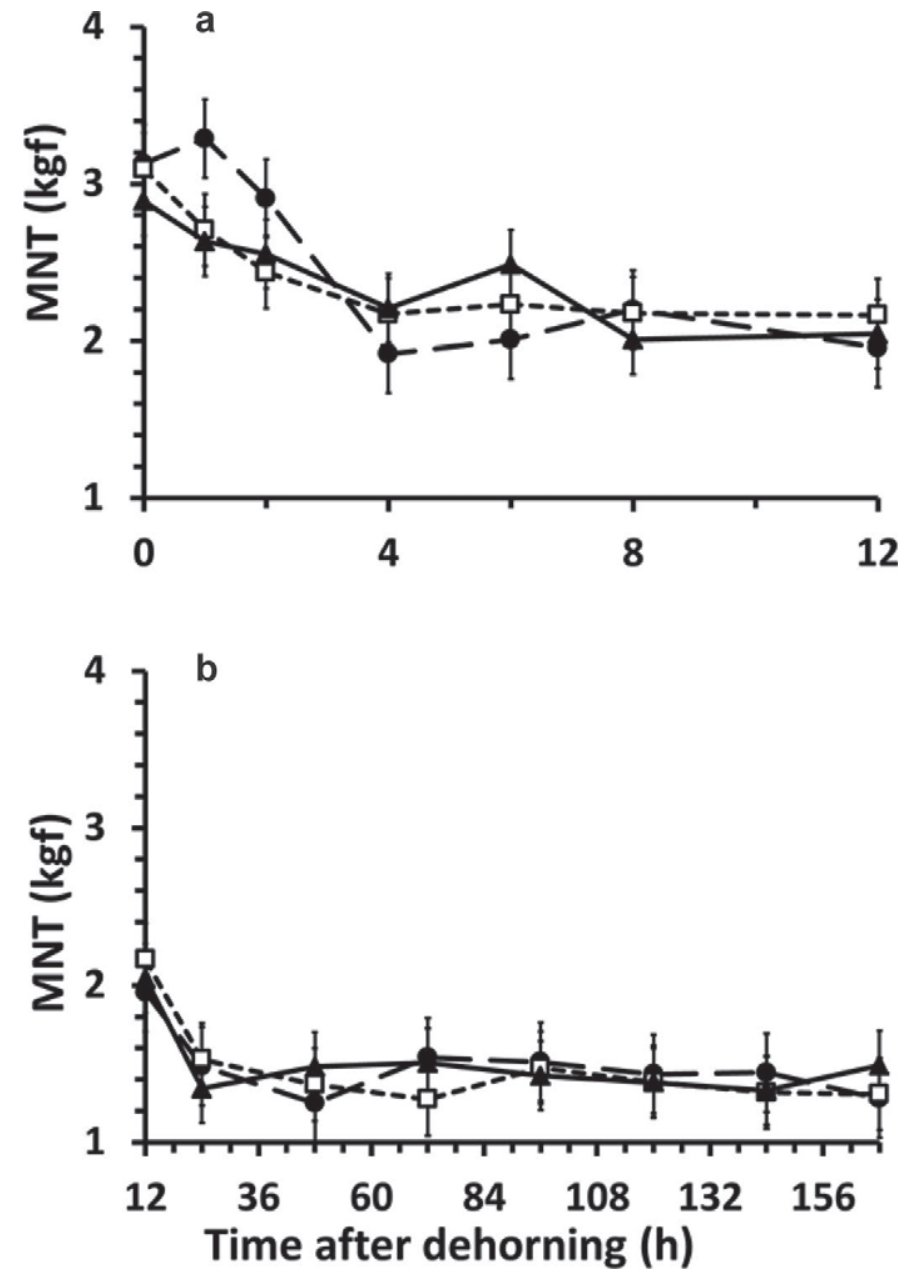

Figure 6. Mean \pm SEM mechanical nociceptive threshold (MNT; kgf) in dairy calves dehorned $(\mathrm{n}=10$ calves/group) with meloxicam administration $12 \mathrm{~h}$ before dehorning $(\mathbf{\Lambda})$, meloxicam administered at the time of dehorning $(\square)$, and control group with no meloxicam administered $(\bullet)$. Time of dehorning was designated as time 0 . Control calves tolerated more force than meloxicam-treated calves at $3 \mathrm{~h}$ after dehorning $(P=0.02)$ but meloxicam-treated calves tended to tolerate more force at $8 \mathrm{~h}$ after dehorning $(P=0.07)$.

whereas the coadministration of a local anesthetic and an NSAID has been shown to mitigate the pain response after the effect of the local anesthetic is diminished (about 2-3 h postdehorning), the effect of timing of NSAID administration before the onset of pain has not been studied (McMeekan et al., 1998; Stewart et al., 2009). The present study found no clinically significant difference between meloxicam administered in the milk replacer $12 \mathrm{~h}$ before dehorning compared with meloxicam administered as a bolus at the time of dehorning. These results provide support for the use of oral meloxicam as an analgesic compound administered at the time of dehorning in preweaning Holstein calves.

The pharmacokinetics of oral meloxicam administered to calves as a bolus or in milk replacer has been 


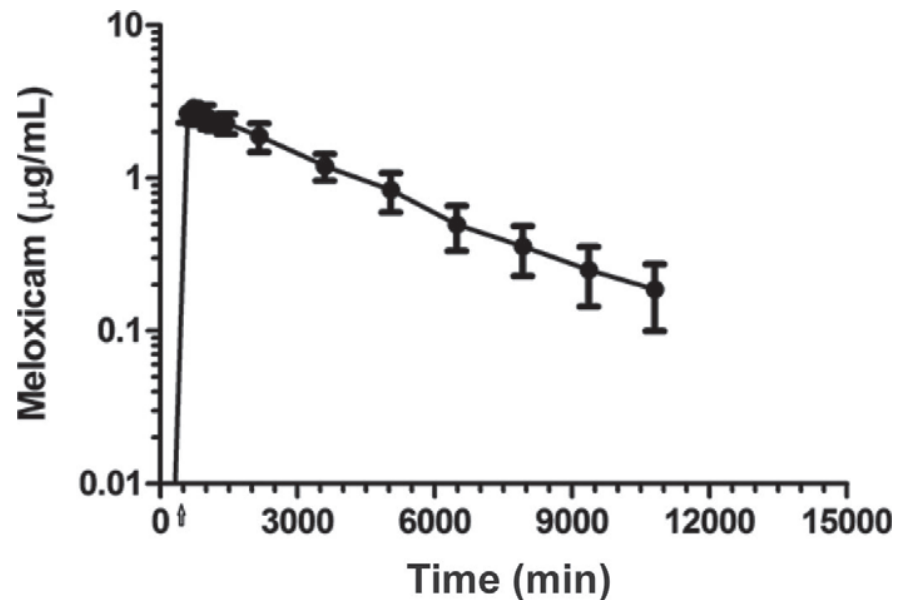

Figure 7. Mean \pm SEM of the plasma meloxicam concentration after oral administration of $1 \mathrm{mg} / \mathrm{kg}$ dissolved in milk replacer and administered $12 \mathrm{~h}$ before dehorning (arrow) in the calves receiving meloxicam administration $12 \mathrm{~h}$ before dehorning.

described (Mosher et al., 2012). In the present study, time to maximum concentration was in agreement with what has previously been reported. However, the $\mathrm{C}_{\max }$ for both MEL-PRE $(3.61 \mu \mathrm{g} / \mathrm{mL})$ and MEL-POST (3.27 $\mu \mathrm{g} / \mathrm{mL}$ ) treatment groups was approximately twice the $\mathrm{C}_{\max }$ of a previous study (Mosher et al., 2012). This outcome was anticipated given that a dose of $1 \mathrm{mg} / \mathrm{kg}$, as opposed to a $0.5 \mathrm{mg} / \mathrm{kg}$ dose, was administered in the present study. The reason for increasing the dose was to add an additional half-life to the plasma drug concentration versus time curve, which we hypothesized would extend the duration of analgesia following oral meloxicam administration.

Regardless of treatment, cortisol concentrations were above baseline concentrations for $30 \mathrm{~min}$ following dehorning. This suggests that the surgical procedure caused some distress in calves despite the use of local

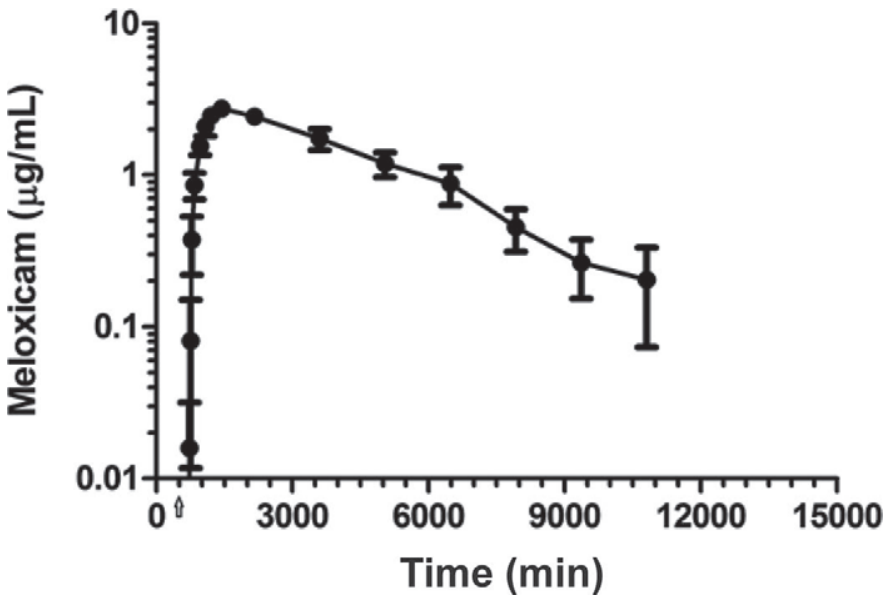

Figure 8. Mean \pm SEM of the plasma meloxicam concentration after oral administration of $1 \mathrm{mg} / \mathrm{kg}$ administered at the time of dehorning (arrow) in the calves administered meloxicam at the time of dehorning.

anesthesia. However, at $4 \mathrm{~h}$ postdehorning, serum cortisol concentrations in CONT calves were significantly higher than either MEL-PRE- or MEL-POST-treated calves. A similar increase in cortisol concentration in calves dehorned without systemic analgesia has been previously reported at $1.5 \mathrm{~h}$ postdehorning and has been attributed to the effects of the local anesthetic decreasing (Stafford and Mellor, 2005; Heinrich et al., 2009). Although the cortisol response in the CONT calves in the present study occurred later than in other trials, this response likely coincides with the return of sensitivity to the previously anesthetized horn bud. The absence of a cortisol response in meloxicam-treated calves at $4 \mathrm{~h}$ postdehorning can likely be attributed to the analgesic effect of the drug as has previously been described following parenteral meloxicam administration (Heinrich et al., 2009). The results of the present

Table 1. Mean \pm SEM meloxicam pharmacokinetic parameters in dairy calves dehorned ( $\mathrm{n}=10$ /group) with meloxicam administration $12 \mathrm{~h}$ before dehorning (MEL-PRE) and meloxicam administered at the time of dehorning (MEL-POST)

\begin{tabular}{|c|c|c|c|c|c|c|}
\hline Parameter & Group & Mean \pm SEM & SD & Lower $95 \%$ & Upper $95 \%$ & $P$-value ${ }^{1}$ \\
\hline \multirow[t]{2}{*}{ Terminal half-life (h) } & MEL-POST & $35.81 \pm 6.26$ & 19.79 & 21.65 & 49.97 & 0.488 \\
\hline & MEL-PRE & $38.62 \pm 5.87$ & 17.61 & 25.08 & 52.16 & \\
\hline Time to maximum plasma concentration (h) & MEL-POST & $15.0 \pm 2.17$ & 6.85 & 10.10 & 19.90 & 0.838 \\
\hline \multirow[t]{2}{*}{ Maximum plasma concentration $(\mu \mathrm{g} / \mathrm{mL})$} & MEL-POST & $3.27 \pm 0.14$ & 0.46 & 2.94 & 3.40 & 0.191 \\
\hline & MEL-PRE & $3.61 \pm 0.21$ & 0.62 & 3.14 & 4.08 & \\
\hline $\begin{array}{l}\text { Area under the curve from time } 0 \text { to infinity } \\
(\mathrm{h} \cdot \mu \mathrm{g} / \mathrm{mL})\end{array}$ & MEL-POST & $217.53 \pm 38.20$ & 120.80 & 131.11 & 303.94 & 0.653 \\
\hline Plasma clearance per fraction & MEL-POST & $0.10 \pm 0.02$ & 0.05 & 0.06 & 0.14 & 0.967 \\
\hline of the dose absorbed ( $\mathrm{mL} / \mathrm{min}$ per $\mathrm{kg})$ & MEL-PRE & $0.10 \pm 0.01$ & 0.03 & 0.06 & 0.12 & \\
\hline
\end{tabular}

${ }^{1} P$-values represent statistical comparison of the MEL-PRE and MEL-POST pharmacokinetic parameters. 
study, therefore, provide support for the hypothesis that oral meloxicam has a similar analgesic effect to parenteral meloxicam.

Haptoglobin has been suggested as an alternative to serum cortisol to determine the extent of tissue damage and the effect of analgesic compounds in calves (Earley and Crowe, 2002). However, the results of the present study did not find any significant differences in haptoglobin concentration associated with meloxicam administration. Haptoglobin is an acute phase protein that increases in association with an inflammatory response. Earley and Crowe (2002) found that ketoprofen administration either alone or in combination with a local anesthetic reversed the increase in haptoglobin concentrations in surgically castrated calves at $24 \mathrm{~h}$ after castration. Furthermore, on d 3 postcastration, concentrations of haptoglobin were lower in ketoprofentreated calves than calves that did not receive ketoprofen (Earley and Crowe, 2002). One explanation for the observed difference in haptoglobin concentrations is that Earley and Crowe (2002) used 5.5-mo-old castrated bull calves, whereas the present study used 8- to 10 -wk-old calves that were subjected to hot iron dehorning. It is reasonable to assume that differences in age and procedure influenced the outcome with respect to haptoglobin concentrations (Mellor et al., 2000).

Substance P is a neuropeptide that regulates excitability of the dorsal horn nociceptive neurons and may be stimulated in times of pain, stress, and anxiety (Coetzee, 2011). It has previously been reported that, despite similar plasma cortisol concentrations, castrated calves had a significantly elevated plasma SP concentration when compared with simulated-castrated beef calves (Coetzee et al., 2008). Furthermore, the same research group recently reported that an i.v. injection of meloxicam significantly reduced plasma SP concentrations in calves after dehorning, and that an inverse relationship exists between plasma meloxicam concentrations and SP concentrations (Coetzee et al., 2012). The present study provides further evidence to support the finding that meloxicam suppresses plasma SP concentrations after dehorning, and that oral meloxicam dosing has similar effects to those observed following parenteral injection.

No effect of timing of meloxicam administration on the mechanical nociceptive threshold measured by algometer was observed. These results are most likely due to the local anesthetic administered to all calves, including CONT calves. This conclusion is supported by the observation that all groups of calves increased their force tolerance above baseline in the $4 \mathrm{~h}$ postdehorning. The observation that the effect of the local anesthesia lasted approximately $4 \mathrm{~h}$ in this study is further supported by the presence of a spike in cortisol concentration in CONT calves at $4 \mathrm{~h}$ postdehorning, as illustrated in Figure 1. However, at $48 \mathrm{~h}$ postdehorning, calves given meloxicam, regardless of timing, had a significantly increased MNT when compared with CONT calves. The association between increased MNT and analgesia in the present study is supported by the presence of quantifiable meloxicam concentrations in the plasma of treated calves at this time point. This observation supports the finding of Heinrich et al. (2010), who first reported that meloxicam-treated calves had a greater tolerance to force at the disbudding site at $24 \mathrm{~h}$ postdehorning compared with control calves. This suggests that the effect of oral meloxicam is similar to parenteral meloxicam in alleviating pain following disbudding.

No significant differences in maximum ocular temperature were detected between treatments. However, the ocular temperature did decrease in all calves from baseline for the $1 \mathrm{~min}$ pre- and 1 min postdehorning. This finding can most likely be attributed to epinephrine release following handling, which causes sympathetic stimulation and constriction of the vasculature supplying the eye and results in a decrease in ocular temperature. However, because the temperature had dropped before dehorning, it is probably indicative of stress not directly associated with pain. Whereas these results are in accordance with previous work that found that exogenous stimulation of the sympathetic nervous system tended to cause a decrease in ocular temperature, these findings did not show a unique response to pain (Stewart et al., 2007). Further research is needed before ocular temperature determination can be recommended as an objective method of pain assessment in cattle.

A key finding in this study was that $\mathrm{PgE}_{2}$ concentrations following ex vivo stimulation of whole blood with LPS were significantly lower in MEL-PRE- and MEL-POST-treated calves compared with CONT calves over $24 \mathrm{~h}$ postdehorning. These results were expected because NSAID reduce prostaglandin synthesis by inhibiting the enzyme cyclooxygenase (COX). Prostaglandin $\mathrm{E}_{2}$ is a prostaglandin generally associated with inflammation and fever and believed to have a significant effect on pain modulation (Myers et al., 2009). Meloxicam is a COX-2-selective NSAID that reduces the production of prostaglandins, in particular $\mathrm{PgE}_{2}$, by inhibiting COX-2 and thus reducing pain associated with inflammation (Anderson and Muir, 2005). The findings of the present study demonstrate that meloxicam in the plasma of treated calves suppressed $\mathrm{PgE}_{2}$ synthesis ex vivo because meloxicam-treated calves had a significantly lower $\mathrm{PgE}_{2}$ than CONT calves. These findings support the results of previous in vitro studies that showed that an NSAID can inhibit 
the formation of $\mathrm{PgE}_{2}$ (Myers et al., 2009; Fraccaro et al., 2013). Interestingly, meloxicam administration 12 $\mathrm{h}$ before dehorning only suppressed $\mathrm{PgE}_{2}$ synthesis for approximately $12 \mathrm{~h}$ postdehorning, after which $\mathrm{PgE}_{2}$ concentrations were similar to those recorded in CONT calves. However, meloxicam administration at the time of dehorning suppressed $\mathrm{PgE}_{2}$ concentrations for up to $3 \mathrm{~d}$ postdehorning. This was the only significant difference observed in relation to timing of meloxicam administration. Whereas postemptive administration of meloxicam did show a longer suppression of $\mathrm{PgE}_{2}$ concentration indicating a longer duration of action than the pre-emptive administration of meloxicam, no other biomarker supported this finding. Given that no validated biomarkers of pain in cattle currently exist, further research is necessary to determine if $\mathrm{PgE}_{2}$ is an appropriate measure of pain and to determine the clinical relevance of the differences observed in the present study. To our knowledge, this is the first published report that compares the effects of meloxicam on $\mathrm{PgE}_{2}$ synthesis when administered preemptively versus postprocedure. Further investigation is necessary to evaluate the potential benefits of preemptive analgesia using more sensitive outcome measures.

Meloxicam is not currently approved for use in food animals in the United States (Coetzee, 2011). Therefore, all current use of meloxicam for pain management in cattle is considered to be ELDU and such use must comply with the regulations described in the AMDUCA. Flunixin meglumine is an approved NSAID for use in cattle; however, when used for relief of pain, it is also considered an ELDU and must therefore comply with AMDUCA regulations. Significant differences between flunixin meglumine and meloxicam, including the purported COX-2 selectivity of meloxicam and the $4 \times$ longer plasma elimination half-life of meloxicam compared with flunixin meglumine (Coetzee et al., 2009), may make meloxicam a more attractive choice in pain management. Although oral meloxicam offered in the milk replacer $12 \mathrm{~h}$ before dehorning may be preferable because of ease of administration and convenience, it is important to note that AMDUCA regulations state that ELDU for mass medication in feed is prohibited "without limitation or exception" (Payne et al., 1999). However, the US Food and Drug Administration "generally has not objected to mixing a drug with an individual animal's feed" as was used in the present study (Payne et al., 1999).

The present study found no significant difference in pharmacokinetic parameters or physiological biomarkers measured in this trial between calves that received pre-emptive versus postemptive meloxicam. This may be because all animals also received local anesthesia before dehorning. Previous studies involving parenteral meloxicam administration have typically reported few differences in the biomarkers assessed after $24 \mathrm{~h}$. In the present study, the combined effect of local anesthesia and the use of biomarkers that remained unchanged after $24 \mathrm{~h}$ suggest that this model may have been too insensitive to detect potential benefits of pre-emptive versus postemptive analgesia. Furthermore, the results of the present study suggest that, although meloxicam administration in the milk replacer may be convenient and cost-effective for producers to use, this route of administration does not provide any quantifiable benefits with respect to analgesia compared with treatment at the time of the procedure based on the outcomes that were measured.

Taken together, the results of the present study have confirmed that meloxicam, regardless of time of administration, suppresses a pain response following dehorning. This finding is significant considering that no previous study has reported the effects of oral meloxicam following dehorning on these outcomes. Given that dehorning is a common practice in the United States and no approved methods for extended pain relief following this procedure currently exist, the results of the present study affects the development of analgesic drug regimens on livestock production systems. Furthermore, we provide evidence to suggest that $\mathrm{PgE}_{2}$ concentrations may be a sensitive measure of the duration of NSAID effects in cattle. Whereas meloxicam mitigated $\mathrm{PgE}_{2}$ response irrespective of the time of administration, only meloxicam given at the time of dehorning reduced $\mathrm{PgE}_{2}$ concentrations for an extended period after dehorning. The findings in the present study indicate that oral meloxicam provides analgesia following dehorning comparable to what has been previously reported after parenteral administration. Furthermore, ex vivo assessment of $\mathrm{PgE}_{2}$ synthesis following LPS stimulation is a sensitive biomarker for assessing the pharmacodynamics of different NSAID regimens.

\section{ACKNOWLEDGMENTS}

This project was supported by Agriculture and Food Research Initiative Competitive Grant no. 2009-6512005729 from the USDA National Institute of Food and Agriculture. J. F. Coetzee was supported by Agriculture and Food Research Initiative Competitive Grant \#2008-35204-19238 from the USDA National Institute of Food and Agriculture. Special thanks to Kara Smith and Colleen Hill of Kansas State University (Manhattan), the Kansas State University Beef Cattle Research Center staff (Manhattan), and the student workers who made this project possible. Thanks also to Juan S. Velez 
of Aurora Organic Dairy for providing the calves and to Christopher Schuetze (Land O' Lakes Inc., Arden Hills, $\mathrm{MN}$ ) for the partial donation of milk replacer.

\section{REFERENCES}

Anderson, D. E., and W. W. Muir. 2005. Pain management in cattle. Vet. Clin. North Am. Food Anim. Pract. 21:623-635.

AVMA (American Veterinary Medical Association). 2012. Welfare implications of the dehorning and disbudding of cattle. Accessed Dec. 22, 2011. https://www.avma.org/KB/Resources/Backgrounders/ Pages/Welfare-Implications-of-Dehorning-and-Disbudding-Cattle. aspx.

Baldridge, S. L., J. F. Coetzee, S. S. Dritz, J. B. Reinbold, R. Gehring, J. Havel, and B. Kukanich. 2011. Pharmacokinetics and physiologic effects of intramuscularly administered xylazine hydrochlorideketamine hydrochloride-butorphanol tartrate alone or in combination with orally administered sodium salicylate on biomarkers of pain in Holstein calves following castration and dehorning. Am. J. Vet. Res. 72:1305-1317.

Coetzee, J. F. 2011. Invited review: A review of pain assessment techniques and pharmacological approaches to pain relief after bovine castration in the United States. Appl. Anim. Behav. Sci. 135:192213.

Coetzee, J. F. 2013. A review of analgesic compounds used in food animals in the United States. Vet. Clin. North Am. Food Anim. Pract. 29:11-28.

Coetzee, J. F., R. Gehring, A. C. Bettenhausen, B. V. Lubbers, S. E. Toerber, D. U. Thomson, B. KuKanich, and M. D. Apley. 2007. Attenuation of acute plasma cortisol response in calves following intravenous sodium salicylate administration prior to castration. J. Vet. Pharmacol. Ther. 30:305-313.

Coetzee, J. F., B. V. Lubbers, S. E. Toerber, R. Gehring, D. U. Thomson, B. J. White, and M. D. Apley. 2008. Plasma concentrations of substance $\mathrm{P}$ and cortisol in beef calves after castration or simulated castration. Am. J. Vet. Res. 69:751-762.

Coetzee, J., B. KuKanich, R. Mosher, and P. S. Allen. 2009. Pharmacokinetics of intravenous and oral meloxicam in ruminant calves. Vet. Ther. 10:E1-E8.

Coetzee, J. F., R. A. Mosher, B. Kukanich, R. Gehring, B. Robert, J. B. Reinhold, and B. J. White. 2012. Pharmacokinetics and effect of intravenous meloxicam in weaned Holstein calves following scoop dehorning without anesthesia. BMC Vet. Res. 8:153.

Earley, B., and M. A. Crowe. 2002. Effects and ketoprofen alone or in combination with local anesthesia during the castration of bull calves on plasma cortisol, immunological, and inflammatory responses. J. Anim. Sci. 80:1044-1052.

EMEA (European Agency for the Evaluation of the Medicinal Products). 1999. Committee for Veterinary medicinal products. Meloxicam summary report. Accessed Jan. 22, 2013. http://www.ema. europa.eu/docs/en_GB/document_library/Maximum_Residue_ Limits_-_Report/2009/11/WC500014941.pdf.

Faulkner, P. M., and D. M. Weary. 2000. Reducing pain after dehorning in dairy calves. J. Dairy Sci. 83:2037-2041.

FDA (Food and Drug Administration Center for Veterinary Medicine). 2006. Guidance for industry: Development of target animal safety and effectiveness data to support approval of non-steroidal anti-inflammatory drugs (NSAIDS) in animals. Accessed Sep. 11, 2010. www.fda.gov/downloads/AnimalVeterinary/Guidance complianceEnforcement/Guidancef orIndustry/UCM052663.pdf.

Fraccaro, E, JF Coetzee, R Odore, LN Edwards-Callaway, B Kukanich, P Badino, L Bertolotti, H Glynn, J Dockweiler, K Allen, and L Bergamasco.. 2013. A study to compare circulating flunixin, meloxicam and gabapentin concentrations with prostaglandin $\mathrm{E}(2)$ levels in calves undergoing dehorning. Res. Vet. Sci. 95:204-211. http://dx.doi.org/10.1016/j.rvsc.2013.01.018.
Fulwider, W. K., T. Grandin, B. E. Rollin, T. E. Engle, N. L. Dalsted, and W. D. Lamm. 2008. Survey of dairy management practices of one hundred thirteen north central and northeastern United States dairies. J. Dairy Sci. 91:1686-1692.

Health Canada. 2011. Drug product database. Accessed Jan. 22, 2013. http://hc-sc.gc.ca/dhp-mps/consultation/vet/consultations/mrllmr-vdd-dmv-2011-1_lett-eng.php.

Heinrich, A., T. F. Duffield, K. D. Lissemore, E. J. Squires, and S. T. Millman. 2009. The impact of meloxicam on postsurgical stress associated with cautery dehorning. J. Dairy Sci. 92:540-547.

Heinrich, A., T. F. Duffield, K. D. Lissemore, and S. T. Millman. 2010. The effect of meloxicam on behaviour and pain sensitivity on dairy calves following cautery dehorning with a local anesthetic. J. Dairy Sci. 93:2450-2457.

McMeekan, C. M., D. J. Mellor, K. J. Stafford, R. A. Bruce, R. N. Ward, and N. G. Gregory. 1998. Effects of local anesthesia of 4 or 8 hours duration on the acute cortisol response to scoop dehorning in calves. Aust. Vet. J. 76:281-285.

Mellor, D. J., C. J. Cook, and K. J. Stafford. 2000. Quantifying some responses to pain as a stressor. Pages 171-198 in The Biology of Animal Stress-Basic Principles and Implications for Animal Welfare. G. P. Moberg and J. A. Mench, ed. CAB International Publishing, Wallingford, UK.

Mosher, R. A., J. F. Coetzee, C. A. Cull, R. Gehring, and B. KuKanich. 2012. Pharmacokinetics of oral meloxicam in ruminant and preruminant calves. J. Vet. Pharmacol. Ther. 35:373-381.

Muir, W. W., and C. J. Woolfe. 2001. Mechanisms of pain and their therapeutic implications. J. Am. Vet. Med. Assoc. 219:1346-1356.

Myers, M. J., M. I. Scott, C. M. Deaver, D. E. Farrell, and H. F. Yancy. 2009. Biomarkers of inflammation in cattle determining the effectiveness of anti-inflammatory drugs. J. Vet. Pharmacol. Therap. 33: 1-8.

Payne, M. A., R. E. Baynes, S. E. Sundlof, A. Craigmill, A. I. Webb, and J. E. Riviere. 1999. Drugs prohibited from extralabel use in food animals. J. Am. Vet. Med. Assoc. 215:28-32.

Rollin, B. E. 2004. Annual meeting keynote address: Animal agriculture and emerging social ethics for animals. J. Anim. Sci. 82:955-964.

Smith, E. R., and S. Modric. 2013. Regulatory considerations for the approval of analgesic drugs for cattle in the United States. Vet. Clin. North Am. Food Anim. Pract. 29:1-10.

Smith, G. W., J. L. Davis, L. A. Tell, A. I. Webb, and J. E. Riviere. 2008. Extralabel use of nonsteroidal anti-inflammatory drugs in cattle. J. Am. Vet. Med. Assoc. 232:697-701.

Stafford, K. J., and D. J. Mellor. 2005. Dehorning and disbudding distress and its alleviation in calves. Vet. J. 169:337-349.

Stewart, M., K. J. Stafford, S. K. Dowling, A. L. Schaefer, and J. R. Webster. 2008. Eye temperature and heart rate variability of calves disbudded with or without local anesthetic. Physiol. Behav. 93:789-797.

Stewart, M., J. R. Webster, G. A. Verkerk, A. L. Schaefer, J. J. Colyn, and K. J. Stafford. 2007. Non-invasive measurement of stress in dairy cows using infared thermography. Physiol. Behav. 92:520525

Stewart, M., J. M. Stookey, K. J. Stafford, C. B. Tucker, A. R. Rogers, S. K. Dowling, G. A. Verkerk, A. L. Schaefer, and J. R. Webster. 2009. Effects of local anesthetic and a nonsteroidal anti-inflammatory drug on pain responses of dairy calves to hot-iron dehorning. J. Dairy Sci. 92:1512-1519.

Stock, M. L., S. L. Baldridge, D. Griffin, and J. F. Coetzee. 2013. Bovine dehorning: Assessing pain and providing analgesic management. Vet. Clin. North Am. Food Anim. Pract. 29:103-133. http://dx.doi.org/10.1016/j.cvfa.2012.11.001.

US FDA. 1994. Animal Medicinal Drug Use Clarification Act of 1994 (AMDUCA). Accessed Jan. 2012. http://www.fda gov/RegulatoryInformation/Legislation/FederalFoodDrugand CosmeticActFDCAct/SignificantAmendmentstotheFDCAct/ AnimalMedicinalDrugUseClarificationActAMDUCAof1994/ default.htm. 